\title{
Challenges of Integrating Technologies for Learning: Introduction to the IJELLO Special Series of Chais Conference 2010 Best Papers
}

\author{
Yoram Eshet-Alkalai, Avner Caspi, Sigal Eden, \\ Nitza Geri, Edna Tal-Elhasid, and Yoav Yair \\ The Open University of Israel \\ Raanana, Israel
}

\begin{abstract}
yorames@openu.ac.il; avnerca@openu.ac.il; sigaled@openu.ac.il; nitzage@openu.ac.il; ednata@openu.ac.il;yoavya@openu.ac.il
\end{abstract}

\begin{abstract}
The adaptation of innovative technologies for learning and teaching faces learners, developers and instructors with a wide range of challenges that should be considered for a successful implementation. This Interdisciplinary Journal of E-Learning and Learning Objects (IJELLO) second issue of special series is based on selected best papers presented in the Fifth Chais Conference on Instructional Technologies Research 2010: Learning in the Technological Era, which was held at The Open University of Israel, Raanana, Israel, on February 10, 2010, and was organized by the Chais Research Center for the Integration of Technology in Education.

This preface presents the mission and activities of the Chais research center, describes the objectives and themes of the Chais Conference 2010, explains its synergies with IJELLO and the Informing Science Institute, and introduces the papers included in this special issue.
\end{abstract}

Keywords: instructional technologies, e-learning, technology integration in education, diffusion of innovation, human-computer interaction, usability, collaborative learning.

\section{Introduction}

The technologies that we use for teaching and learning are characterized by three major affinities:

- Most of them are developed for organizational, entertainment, and communication management purposes in civilian and military organizations, and not inherently for educational purposes. It is the responsibility of instructional designers to modify and adapt them for educational goals.

Material published as part of this publication, either on-line or in print, is copyrighted by the Informing Science Institute. Permission to make digital or paper copy of part or all of these works for personal or classroom use is granted without fee provided that the copies are not made or distributed for profit or commercial advantage AND that copies 1) bear this notice in full and 2) give the full citation on the first page. It is permissible to abstract these works so long as credit is given. To copy in all other cases or to republish or to post on a server or to redistribute to lists requires specific permission and payment of a fee. Contact 0HPublisher@InformingScience.org to request redistribution permission.
- Technologies-enabled learners' interactions call for reconsidering the traditional pedagogical routines, revisiting learning theories, reconstructing learning environments, and reshaping student-teacher, as well as student-student, relationships.

- They undergo continuous and rapid changes, which require a constant change in the models used for inte- 
gration and utilization of these technologies for teaching and learning.

This situation presents five major challenges for users and developers of instructional technologies:

1. In designing learning environments, developers must consider the particular cognitive, emotional, and ergonomic skills that are required in order to use these environments effectively.

2. Educators must improve their understanding of the nature and pedagogical potential of each of the available learning technologies.

3. Learning theories should take into account the knowledge gained from the implementation of learning technologies.

4. New instructional models and strategies for employing new technologies should be developed.

5. Research is needed to improve our understanding of the impact of using technologies on learners' achievements and attitudes.

A community of researchers and practitioners who collaborate with each other is required in order to cope successfully with the above-listed challenges, and this is the main mission of the Chais Research Center and the "Learning in the Technological Era" annual Conferences.

The Chais Research Center for the Integration of Technology in Education is a consortium of about 50 researchers of the Open University of Israel (OUI) faculty, which serves as the OUI research arm for the study of technologies and their integration in teaching and learning. The mission of the Chais Research Center is to encourage theoretical and practical research at the OUI and to improve the quality and efficiency of utilizing information technologies in learning and teaching. As the major instructional technologies research center in Israel, The Chais Center promotes the formation of a local community of instructional technologies researchers by funding research projects and by holding seminars, symposia, conferences, and study groups.

These are some of the fields of research, which the Chais Center is engaged in:

- The theoretical foundations of learning, instructional technologies and distance education.

- The integration of information and communication technologies into educational systems.

- Defining and characterizing the variables needed for developing flexible and adaptive technology enhanced instructional strategies that respond to students' individual needs.

- Studying the pedagogical and cognitive contributions of emerging technologies on teaching and learning.

"Learning in the Technological Era" is a series of annual national research conferences on learning technologies initiated by the Chais Research Center in collaboration with EDEN, The European Distance and E-Learning Network. The conference contributes to the formation of a community of Israeli researchers in the field of instructional technologies and to the positioning of the Open University of Israel as a leading organization in the study and implementation of learning technologies. About 500 researchers from most of the academic institutions in Israel and from many organizations and companies participate in the conference each year.

The purpose of this IJELLO special series of Chais Conference best papers is to enhance the international impact of the Chais conference by distributing high quality papers from the local conference to worldwide audience. The Informing Science Institute (ISI) is a natural partner for this mission because it draws together researchers and practitioners of information technologies, who seek effective ways to inform clients about sharing their knowledge with others 
(http://www.informingscience.org/). The informing science transdiscipline studies the informing process, defined as providing a specific clientele with information in a form, format, and schedule that maximizes its effectiveness (Cohen, 1999, 2009; Gill \& Cohen, 2009). Instructional technologies are a certain type of information technologies, which aim at providing students and other learners with information and tools to enhance their learning. Within the ISI journals, the Interdisciplinary Journal of E-Learning and Learning Objects publishes high quality articles on theory, practice, innovation, and research that cover all aspects of E-learning and Learning Objects (http://www.ijello.org). The first issue of this series was published last year, and included 13 selected papers, which dealt with various aspects of technology integration in teaching and learning, collaborative learning environments, quality of mobile learning, motivation for technology use, and more (Eshet-Alkalai, Caspi, Eden, Geri, \& Yair, 2009).

\section{Chais Conference 2010 Best Papers}

Out of 75 short papers that were submitted to Chais conference 2010 and underwent a blind peerreview process, 39 papers and 15 posters were presented at the conference and were included in the conference's proceedings volume (Eshet-Alkalai, Caspi, Eden, Geri, \& Yair, 2010). This second issue of the IJELLO Special Series of Chais Conference Best Papers includes nine of the most outstanding Chais Conference 2010 papers, which were expanded and modified for publication in IJELLO and have undergone a full review process by the IJELLO editors and reviewers.

The first three papers of this issue deal with the integration of technology in education systems and diffusion of innovation in learning environments. Ina Blau and Mira Hameirie ("Implementing technological change at schools: The impact of online communication with families on teacher interactions through learning management system") studied the implementation of a learning management system in high schools and found that the use of the system for teacher-student and teacher-parent online interaction significantly enhanced its use for interactions among teachers. Their findings suggest that involving students and parents in the process of implementing new technologies at school may contribute to successful adoption.

Orit Avidov-Ungar ("Islands of innovation" or "comprehensive innovation"”) examined the implementation of a learning management system in seven schools, which were part of a school network. Her qualitative analysis indicates that sporadic "islands of innovation" created an appearance of successful technology implementation when actually no real "comprehensive innovation" occurred.

Zvia Elgali and Yoram Kalman ("Analyzing the construction of the failure and success concepts in K-12 ICT integration projects") used Actor-Network Theory and compared the perceptions of failure and success in the integration of two programs in the K-12 system. They point to several differences between the programs that may be possible causes for the increased level of talk of failure with regard to one of these programs.

Two instructors: Ronen Hammer and Miki Ronen, and their students: Amit Sharon, Tali Lankry, and Yoni Huberman ("Mobile culture in college lectures: Instructors' and students' perspectives") explored college instructors' and students' attitudes towards use of mobile devices, mainly laptops and cellular phones, for non-academic purposes during lectures. One of their most interesting finding is the sense of cognitive dissonance of students who perceive mobile devices use as disturbing instructors and peers and yet believe that such usage is legitimate.

Galit Ben-Zadok, Moshe Leiba, and Rafi Nachmias ("Comparison of online learning behaviors in school vs. at home, in terms of age and gender, using data mining techniques") examined characteristics of online learning at school and at home. They found that the school-home gap is beginning to close, yet there were differences in time and pace, as well as of quality of learning. 
Introduction to the IJELLO Special Series of Chais Conference 2010 Best Papers

Ariela Levenberg and Avner Caspi ("Comparing perceived formal and informal learning in faceto-face versus online environments") compared perceived learning of elementary school teachers in four learning environments: formal - face-to-face; informal - face-to-face; formal - online; informal - online. Their findings suggest that perceived learning was higher in a formal setting, and teachers that communicated online had perceived higher levels of learning.

Ruti Gafni and Nitza Geri ("The value of collaborative e-learning: Compulsory versus optional online forum assignments") analyzed the impact of compulsory submission on the effectiveness of forum assignments. Their results indicate that although the students had a task-oriented attitude and were not engaged in social interaction, compulsory posting on the discussion board improved their performance.

Yehuda Peled and Miriam Sarid ("The effect of procrastination on multi-drafting in a web-based learning content management environment") examined student use of a mechanism that enabled multi-drafting of assignments and their improvement according to the teacher's feedback. Although there was a positive significant correlation between the number of drafts submitted per assignment and the final grade, some of the students did not take advantage of the mechanism offered.

Rikki Rimor, Yigal Rosen, and Kefaya Nassar ("Are two better than one? A study of social interaction patterns in an online collaborative database environment") characterized social interaction patterns in a collaborative learning environment (Google Docs), in which participants were required to reach consensus in the process of database construction. Their analysis suggests that the online database contributes to the development of complex patterns of interaction.

These papers represent most of the themes of the Chais conference 2010 proceedings. The following themes were presented at the conference but were not covered in this special issue: Instructors' training in technological environments; Games and learning environments; Visualization; knowledge representation.

\section{Conclusion and Acknowledgements}

We hope this second issue of IJELLO special series of Chais conference best papers will be of interest to the readers and will encourage future innovative and synergetic instructional technologies research. We look forward to the IJELLO next issue of the best papers of Chais conference 2011, which is scheduled to February 17, 2011, at the Open University of Israel campus in Raanana, Israel.

We would like to express our ongoing gratitude to Alex Koohang, the Editor-in-Chief of the Interdisciplinary Journal of E-Learning and Learning Objects, for his enthusiastic support and encouragement and for conducting this editorial effort.

Special thanks to Eli Cohen and Betty Boyd of the Informing Science Institute for enabling this special series and for the publishing work.

Thanks to all the contributing authors and reviewers for their excellent work. Finally, we would like to thank the community of Israeli instructional technologies researchers and practitioners for participating in Chais conferences and contributing to the development of this important field.

\section{References}

Cohen, E. (1999). Reconceptualizing information systems as a field of the transdiscipline informing science: From ugly duckling to swan. Journal of Computing and Information Technology, 7(3), 213-219. 
Cohen, E. (2009). A philosophy of informing science. Informing Science: the International Journal of an Emerging Transdiscipline, 12, 1-15. Retrieved from http://inform.nu/Articles/Vol12/ISJv12p001015Cohen399.pdf

Eshet-Alkalai, Y., Caspi, A., Eden, S., Geri, N., \& Yair, Y. (2009). Introduction to the IJELLO special series of Chais Conference 2009 best papers. Interdisciplinary Journal of E-Learning and Learning Objects, 5, 181-186. Available at: http://ijello.org/Volume5/IJELLOv5p181-186ChaisPreface.pdf

Eshet-Alkalai, Y., Caspi, A., Eden, S., Geri, N., \& Yair, Y. (Eds.) (2010). Proceedings of the Chais conference on instructional technologies research 2009: Learning in the technological era. Raanana: The Open University of Israel.

Gill, T. G., \& Cohen, E. (Eds.). (2009). Foundations of informing science, 1999-2008. Santa Rosa, CA: Informing Sciences Press.

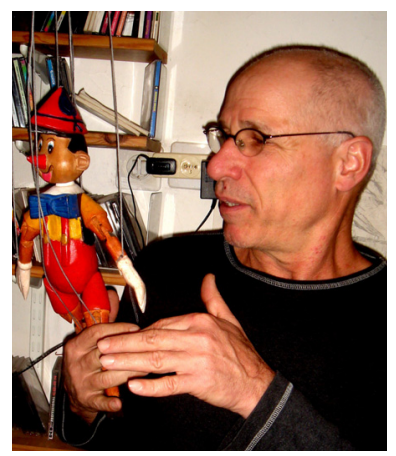

\section{Biographies}

Yoram Eshet-Alkalay is a faculty member at the Open University of Israel, Department of Education \& Psychology. He is the Coordinator of the M.A. program in educational technology and the Head of the Chais Research Center for the Integration of Technology in Education in the Open University. He holds a B.A. in Archeology (Hebrew University), M.Sc. in Geology (Hebrew University) and Ph.D. in Earth \& Environmental Sciences (City University of NY). For a decade, he was the Head of the Instructional Design Program in the Tel Hai Academic College, and a senior researcher in the Geological Survey of Israel. He has 15 years experience in developing technology-based instructional solutions for educational systems in Israel and the USA. In this capacity, he was involved in the design of hundreds of simulations, data-bases, tutorials and large-scale curriculum integration projects. His major research and publications interests focus on cognitive aspects of working with digital technologies, digital games and design principles of computerbased learning environments. Personal site: http://www.openu.ac.il/Personal sites/yorameshet.html

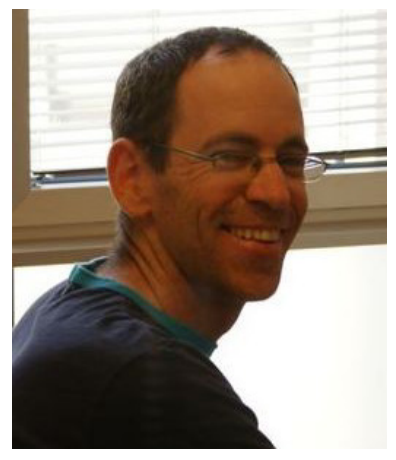

Avner Caspi is a faculty member at the Open University of Israel, Department of Education \& Psychology. He holds a B.A. in Behavioral Sciences (Tel-Aviv Yaffo Academic College), and Ph.D. in Cognitive Psychology (Tel Aviv University). His major research and publications interests focus on social aspects of communication technologies, mainly in the area of learning and instruction. Personal site: http://www.openu.ac.il/Personal_sites/avner-caspi.html

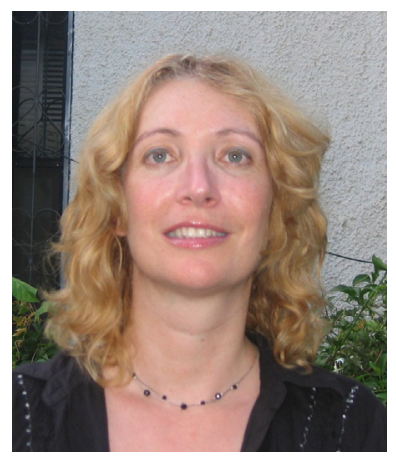

Sigal Eden is a fellow researcher and a member of the Chais Research Centre, the Open University of Israel, and a lecturer of Bar Ilan University, School of Education. She holds a B.A. in Education for Students with Hearing Impairment from Tel-Aviv University, an M.A. and Ph.D. in Educational Technologies from Bar-Ilan University. Her research interests and publications focus on various aspects of working with digital environments, especially the enhancement of cognitive and linguistic aspects among people with special needs. Personal site: http://www.openu.ac.il/research_center_eng/Sigal_Eden_card_E.html 


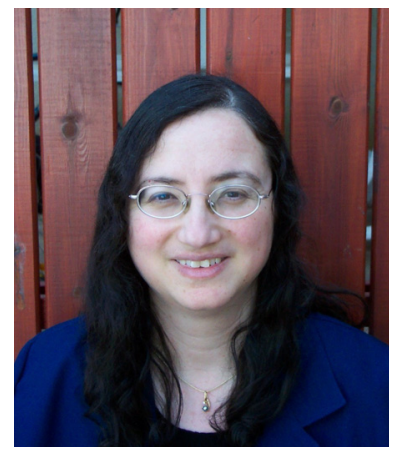

Nitza Geri is Head of the Department of Management and Economics, the Open University of Israel. She holds a B.A. in Accounting and Economics, an M.Sc. in Management Sciences and a Ph.D. in Technology and Information Systems Management from Tel-Aviv University. Nitza is a CPA (Israel) and prior to her academic career she had over 12 years of business experience. Her research interests and publications focus on various aspects of the value of information, and information systems adoption and implementation, including strategic information systems, e-business, value creation and the Theory of Constraints, managerial aspects of e-learning systems adoption and use. Personal site: http://www.openu.ac.il/Personal_sites/nitza-geri.html

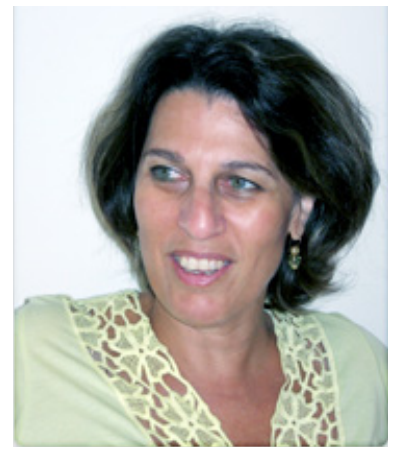

Edna Tal-Elhasid is the Head of the Center for Technologies in Distance Education at the Open University of Israel. She is a member of the Chais Research Center for the Integration of Technology in Education. Edna holds a B.A. in Mathematics and Computer Science from Haifa University, Israel, and an M.A. in Information and Communication Technologies in Education from Tel Aviv University. Her Thesis subject: Visible and invisible presence in online discussion groups of academic courses. Her main areas of interest focus on Open Educational Resources (OER and OCW), digital and audio books, online collaborative learning in higher education, video broadcasts and synchronous voice-over-IP systems, and Online Teaching \& Learning in general. Most of her papers deal with the use of Wiki at the Open University of Israel and the OCW (open courseware) project at the OUI. Personal site: http://www.openu.ac.il/Personal sites/ednatal/profile english.htm

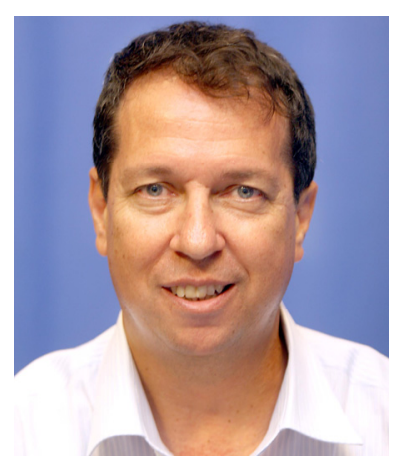

Yoav Yair is Dean of Development and Educational Technology at the Open University of Israel. He is a faculty member at the Open University, Department of Life and Natural Sciences. He is an expert on educational technology, having worked as software designer and educational program developer at the Centre for Educational Technology (CET) in Tel-Aviv for 15 years. His main interests in this field are scientific visualization and desktop virtual reality. He also wrote 4 textbooks for the K-12 Israeli education system and was a chief software designer of several educational software and websites. At the Open University of Israel, in the years 2004-2009, Prof. Yair headed the Center for Technology in Distance Education (SHOAM), tasked with developing, testing, disseminating and evaluating learning technologies for usage in distance education. In this capacity he was responsible for introducing new technologies into the Open University, with emphasis on the academic usage of the OPUS Hebrew-based learning management system, of video broadcasts and synchronous voice-over-IP systems, as well as collaborative tools such as Wikis. Prof. Yair leads the Open Courseware project at the Open University of Israel, with a new initiative to open complete e-books and audio-books on-line for free usage by the general public. Prof. Yair published numerous papers in atmospheric sciences and on the usage of technology in science and distance education. He now leads new projects in mobile e-books for academic courses. Prof. Yair is an atmospheric and space physicist and leads a research team for studying thunderstorms, lightning and their effects on the atmosphere. Another field of research is science education with emphasis on Astronomy and the Earth Sciences. Personal site:

http://www.openu.ac.il/Personal_sites/yoav-yair.html 